\title{
Higher levels of matrix metalloproteinase- 3 in patients with RA reflect disease activity and structural damage
}

\author{
Martina Skacelova ${ }^{a}$, Zuzana Hermanova ${ }^{b}$, Pavel Horaka, Ahmed Kazia ${ }^{a}$ Katerina Langovac
}

\begin{abstract}
Aims. To evaluate the serum levels of matrix metalloproteinase-3 (MMP-3) as a potential marker of disease activity and joint damage in 92 patients with rheumatoid arthritis (RA), compared to 24 osteoarthritis (OA) patients and 26 healthy controls.
\end{abstract}

Methods. The concentrations of MMP-3 were measured by ELISA using the commercial kit AESKULISA DF MMP-3 (AESKU.Diagnostics, Germany) and compared with other laboratory parameters routinely used to assess the disease status, clinical score (DAS28) and radiographic stage in the group of RA patients.

Results. The mean serum concentrations of MMP-3 were $199.1 \pm 160 \mathrm{ng} / \mathrm{mL}$ in RA patients, $113.9 \pm 96.9 \mathrm{ng} / \mathrm{mL}$ in OA patients and $48.3 \pm 19.2$ in healthy controls. The differences were highly significant: RA patients and healthy controls $(P<0.0001)$, RA and OA patients $(P=0.008)$ as well as between OA patients and controls $(P=0.009)$. MMP-3 concentrations were further compared with other laboratory parameters and clinical and structural damage data. There were correlations between MMP-3 and CRP $(r=0.304, P<0.01)$, DAS28 $(r=0.301, P<0.05)$, levels of anti-cyclic citrullinated peptide antibodies $(r=0.241, P<0.05)$, erythrocyte sedimentation rate $(r=0.200, P=0.059)$ and radiographic disease stage $(r=0.197, P=0.063)$.

Conclusion. These results demonstrated that measurement of MMP-3 could become a marker of disease activity in RA patients.

Key words: rheumatoid arthritis, disease activity, matrix metalloproteinase-3

Received: December 12, 2016; Accepted with revision: March 22, 2017; Available online: April 26, 2017 https://doi.org/10.5507/bp.2017.015

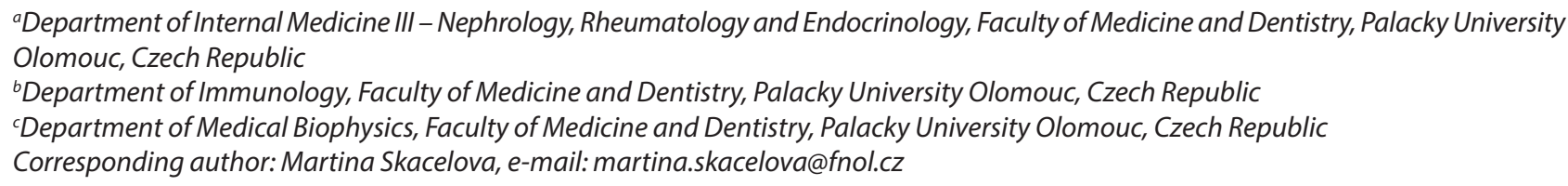

\section{INTRODUCTION}

Rheumatoid arthritis (RA) is a chronic inflammatory disorder of synovial tissue characterized by progressive, erosive and symmetrical polyarthritis associated with various extra-articular manifestations and with variable prognosis, significant morbidity, functional damage, disability and increased mortality. It affects approximately $0.5 \%$ of the adult population ${ }^{1}$. The pathological process leads to destruction of articular cartilage and bone and may eventually result in ankylosis of the affected joints. It is now generally accepted that the activity of cells within synovium and, in particular, the cytokine and enzyme products which they generate are involved in the destruction of underlying matrix components ${ }^{2,3}$. The destruction of connective tissue is also driven by the action of matrix metalloproteinase enzymes (MMPs) released by synovial fibroblasts, chondrocytes and monocytes in response to IL-1 $\beta$, TNF- $\alpha$, interferon gamma, as well as by serum amyloid A (SAA) and epidermal growth factor and platelet- derived growth factor ${ }^{4-8}$. MMPs participate in the maintenance and remodeling of extracellular matrix (ECM) that is important for creating cellular environments. These enzymes have the ability to cleave several constituents of ECM. They play a central role not only in many physiological processes but also in many diseases. Increased activity, caused by either up-regulation of their expression or down-regulation of their inhibitors, is implicated, for example, in arthritis, atherosclerosis and aneurysms, cancer metastases ${ }^{9,10}$, nephritis, skeletal growth-plate disorders, tissue ulcerations and fibrosis ${ }^{11}$. MMP-3 is involved in the pathogenesis of RA as it degrades a range of matrix proteins including proteoglycans, laminin, fibronectin and gelatin found in connective tissue in the synovial joint.

Recent advancement in the treatment of RA require reliable tools for the monitoring of disease activity, evaluation of disease prognosis and choice of the appropriate therapy.

Tracking new markers such as MMP-3 could help identify patients who have a higher risk of pathological changes earlier in the course of the disease and may help in effective intervention with therapy of the disease $^{12-14}$. The present study investigated the association between MMP-3 disease activity and structural involvement with the final objective of assessing and evaluating patient prognosis based on MMP-3 serum levels more effectively. 


\section{OBJECTIVE}

This study aimed to evaluate the serum levels of MMP3 in patients with RA, those with osteoarthritis (OA) of hands and healthy controls to find the association with clinical disease activity, routine tests used in RA and the radiographic stage of disease.

\section{MATERIALS AND METHODS}

\section{Patients}

A total of 92 patients with RA (mean age $54.04 \pm$ 12.22 years; mean disease duration $15.66 \pm 9.04$ years; 60 females and 32 males; mean DAS28 $3.74 \pm 1.47), 24$ patients with OA (mean age $50.12 \pm 15.95$ years, mean disease duration $6.25 \pm 3.43$ years; 17 females and 7 males) and 26 healthy subjects (mean age $48.28 \pm 13.38$ years; 13 females and 13 males) were included in the study after signing informed consent. The study was approved by the local ethic committee of Faculty of Medicine and
Dentistry, Palacký University Olomouc. RA patients met the EULAR/ACR classification criteria for RA (ref. ${ }^{15}$ ) and OA patients met the ACR clinical classification criteria for OA of hand ${ }^{16}$. Twenty-six RA patients $(28.2 \%)$ received biological therapy; the majority of RA patients (84 pts; 91.3\%) were treated with synthetic disease- modifying antirheumatic drugs (DMARDs).

\section{Laboratory analysis}

MMP-3 was measured in serum by ELISA using the commercial kit AESKULISA DF MMP-3 (AESKU. Diagnostics, Germany). The microtiter plate was measured with the ELISA photometer Tecan Spectra (wavelength $450 \mathrm{~nm}$ ). The standard range was $0-800 \mathrm{ng} / \mathrm{mL}$.

The kit measures total MMP-3 (pro- and active MMP-3) and it is a tool for risk stratification of the development of joint destruction and for monitoring disease activity in RA patients. The instruction manual states that the normal ranges are $18-60 \mathrm{ng} / \mathrm{mL}$ and $24-120 \mathrm{ng} / \mathrm{mL}$ for females and males, respectively.

Anti-cyclic citrullinated peptide (CCP) antibodies

Table 1. Demographic data and results of MMP 3 measurement in RA, OA groups and in healthy controls and activity, laboratory and radiographic profile of RA patients.

\begin{tabular}{|c|c|c|c|}
\hline & RA & OA & Healthy controls \\
\hline $\mathrm{N}$ & 92 & 24 & 26 \\
\hline Age (years) & $54.04 \pm 12.22$ & $50.12 \pm 15.95$ & $48.28 \pm 13.38$ \\
\hline $\mathrm{F} / \mathrm{M}$ ratio & $60 / 32$ & $17 / 7$ & $13 / 13$ \\
\hline Duration of disease & $15.66 \pm 9,04$ & $6.25 \pm 3,43$ & NA \\
\hline \multicolumn{4}{|l|}{ MMP-3 (ng/mL) } \\
\hline $\mathrm{x} \pm \mathrm{SD}$ & $199.1 \pm 160$ & $113.9 \pm 96.9$ & $48.3 \pm 19.2$ \\
\hline M & 168 & 64 & 47.5 \\
\hline $\min -\max$ & $26-800$ & $25-367$ & $25-81$ \\
\hline \multicolumn{4}{|l|}{ DAS 28} \\
\hline $\mathrm{x} \pm \mathrm{SD}$ & $3.74 \pm 1.47$ & & \\
\hline $\begin{array}{l}\text { M } \\
\min -\max \end{array}$ & $\begin{array}{c}3.6 \\
1.1-6.84\end{array}$ & NA & NA \\
\hline \multicolumn{4}{|l|}{ CRP $(\mathrm{mg} / \mathrm{mL})$} \\
\hline $\mathrm{x} \pm \mathrm{SD}$ & $12.2 \pm 16.2$ & & \\
\hline M & 4.5 & ND & ND \\
\hline $\min -\max$ & $0.3-89.9$ & & \\
\hline \multicolumn{4}{|l|}{$\operatorname{ESR}(\mathrm{mm} / \mathrm{h})$} \\
\hline $\mathrm{x} \pm \mathrm{SD}$ & $18.9 \pm 15.5$ & & \\
\hline M & 13.9 & ND & ND \\
\hline $\min -\max$ & $1-62$ & & \\
\hline \multicolumn{4}{|l|}{$\mathrm{RF}(\mathrm{IU} / \mathrm{mL})$} \\
\hline $\mathrm{x} \pm \mathrm{SD}$ & $179.8 \pm 242.7$ & & \\
\hline M & 50.7 & NA & NA \\
\hline $\min -\max$ & $10.1-724$ & & \\
\hline \multicolumn{4}{|l|}{ Anti CCP (IU/mL) } \\
\hline $\mathrm{x} \pm \mathrm{SD}$ & $1479.3 \pm 1288.6$ & & \\
\hline M & 1420 & NA & NA \\
\hline $\min -\max$ & $25-3200$ & & \\
\hline \multicolumn{4}{|l|}{ X-ray stage } \\
\hline $\mathrm{x} \pm \mathrm{SD}$ & $2.3 \pm 0.9$ & & \\
\hline M & 2 & NA & NA \\
\hline $\min -\max$ & $1-4$ & & \\
\hline
\end{tabular}

$\mathrm{x}$ - mean, SD - deviation, $\mathrm{M}$ - median, min - minimum, max - maximum, NA-not applicable, ND- not done 


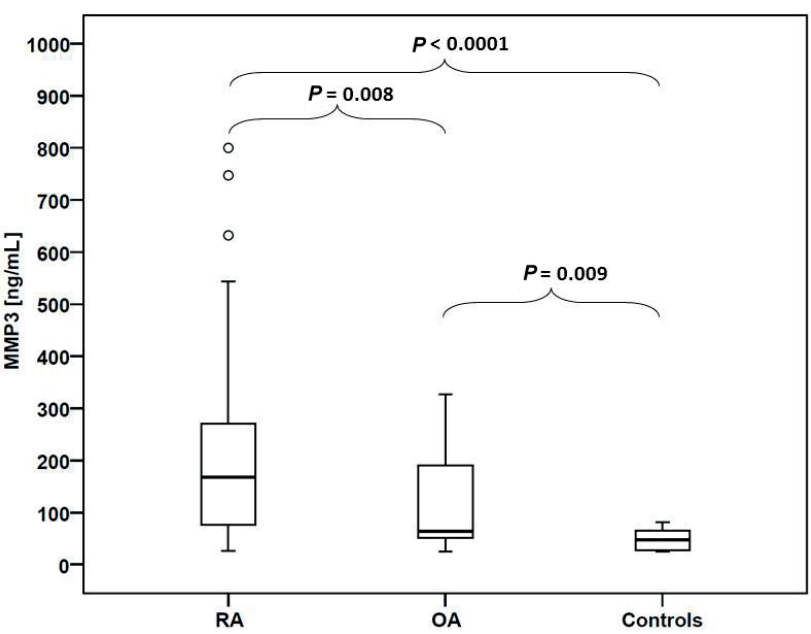

Fig. 1. Differences in serum concentration of MMP-3 between RA patients, OA patients and healthy controls. box shows the distance between the quartiles, with the median as a line, and the whiskers show minimum and maximum values of MMP3. Outliers are shown as separate points. The $P$-values show statistical significances of differences between groups.

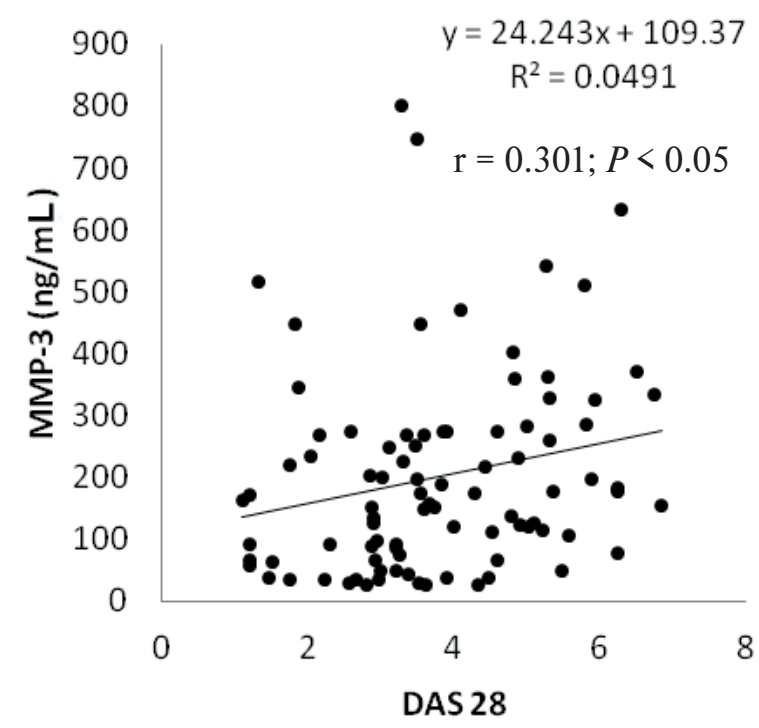

Fig. 3. Correlation between MMP-3 and DAS28.

were measured by ELISA using the Immunoscan CCPlus kit (Euro Diagnostica, Sweden). The standard curve range is $25-3200 \mathrm{U} / \mathrm{mL}$. These values were arbitrarily chosen by Euro Diagnostica since no generally recognized international standard exists for expressing the titer of antiCCP antibodies ${ }^{17}$. Samples with results below $25 \mathrm{U} / \mathrm{mL}$ are defined as negative.

Rheumatoid factor (RF) was measured by nephelometry using the BN II system and N Latex RF Kit (Siemens, Germany). The result is evaluated by comparison with a standard of known concentration ${ }^{18}$. Samples with results below $15 \mathrm{IU} / \mathrm{mL}$ are defined as negative.

Erythrocyte sedimentation rate (ESR) was determined using the Westergren method. The rate of fall of red blood

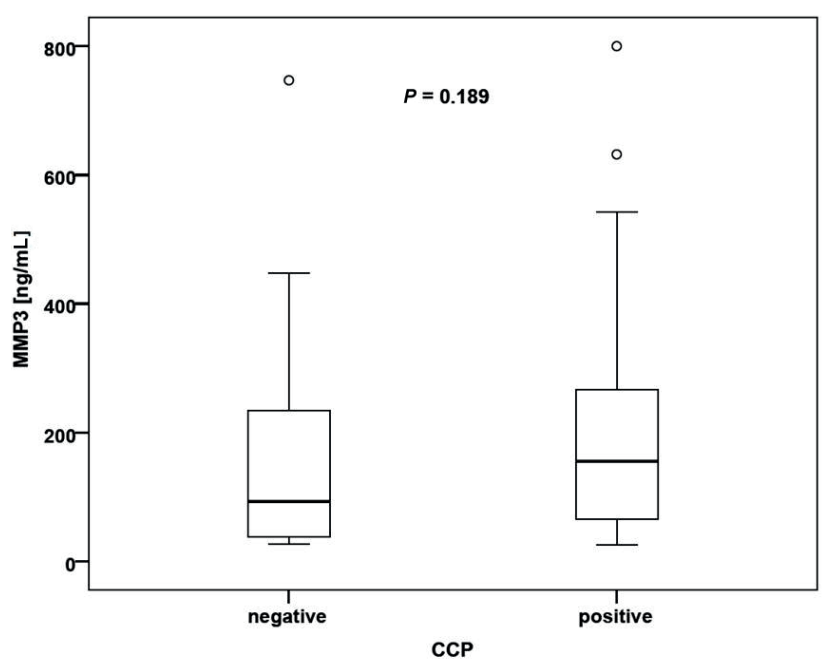

Fig. 2. MMP-3 serum levels in anti-CCP negative and anti-CCP positive RA patients. Box shows the distance between the quartiles, with the median as a line, and the whiskers show minimum and maximum values of MMP3. Outliers are shown as separate points. The P-value show statistical significance of differences between groups.

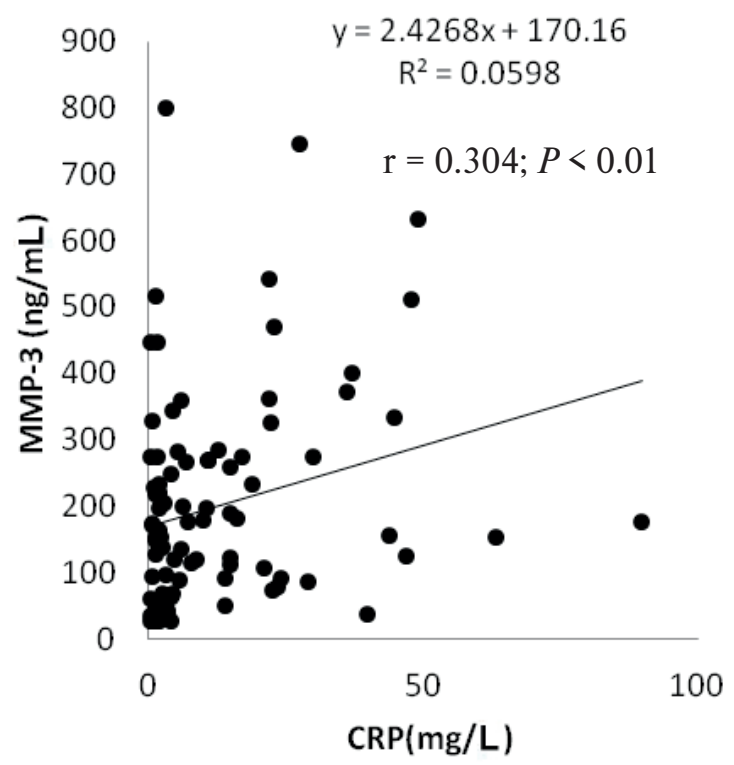

Fig. 4. Correlation between MMP-3 and CRP.

cells is measured in millimeters after in $1 \mathrm{~h}$. The normal rates are $0-15 \mathrm{~mm}$ (mean, $4 \mathrm{~mm}$ ) for males and 0-20 mm (mean, $5 \mathrm{~mm}$ ) for females ${ }^{19}$.

\section{Clinical assessment}

Disease activity score (DAS28) $\left(\right.$ ref. $\left.{ }^{20}\right)$ was measured by a single assessor. Radiographic stage of disease was evaluated according to the Steinbrocker method ${ }^{21,22}$.

Statistical analysis: The Shapiro-Wilk test of normality revealed non-normal distribution of the data. The data were expressed as mean, standard deviation, median, minimal and maximal value. Differences between independent groups were analyzed by the Kruskal-Wallis test and post hoc tests with Bonferroni correction. Differences between 


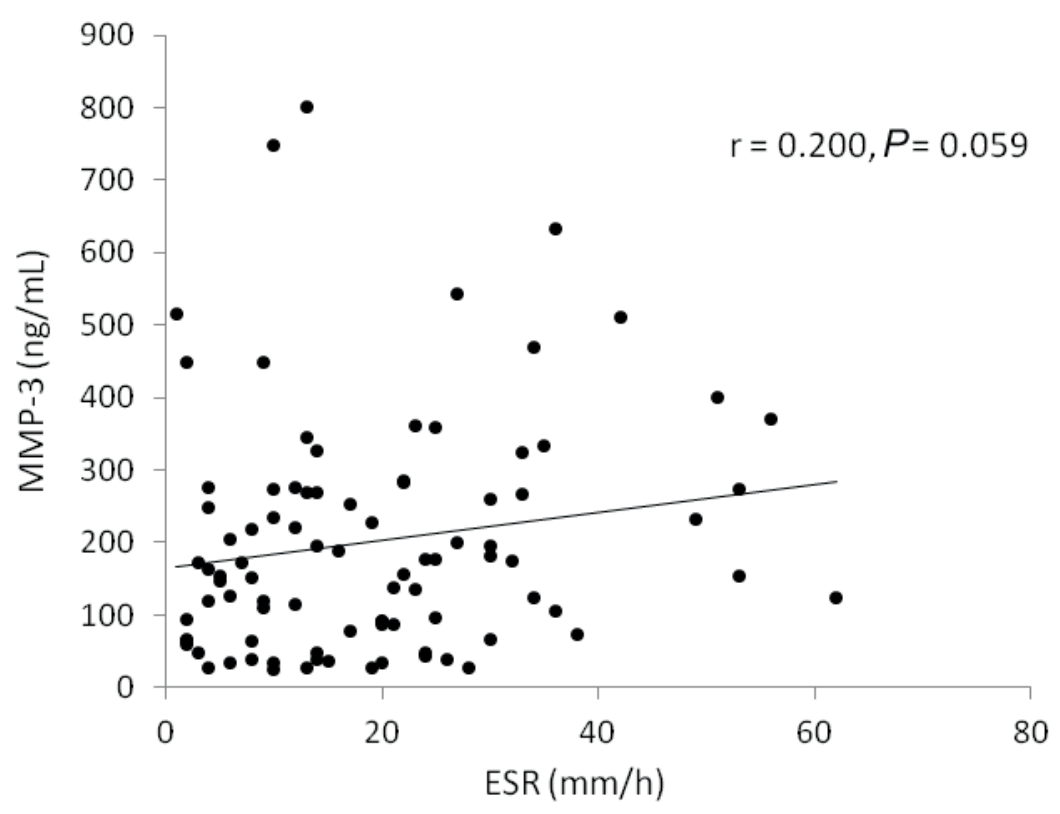

Fig. 5. Correlation between MMP-3 and ESR.

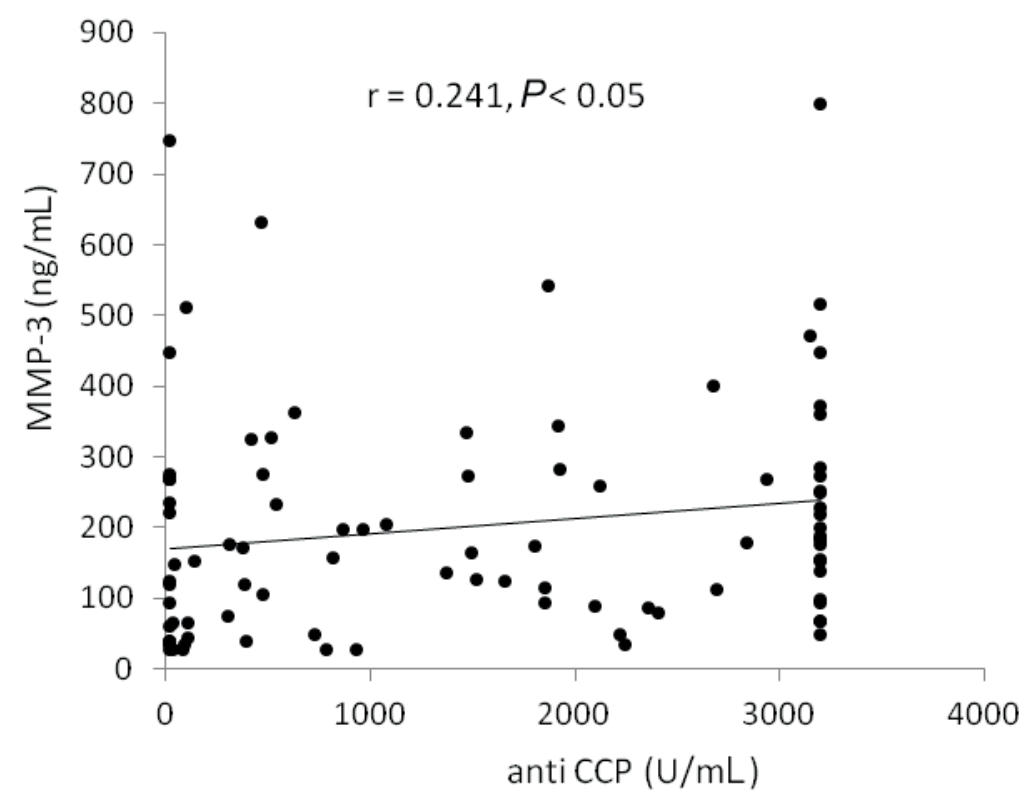

Fig. 6. Correlation between MMP-3 and anti CCP antibodies.

two groups were analysed using Mann-Whitney U-test. Correlations were sought using Spearman's correlation analysis. Values with $P$ less than 0.05 were considered statistically significant. All statistical analyses were conducted with IBM SPSS Statistics 23 (IBM Corporation, 2015).

\section{RESULTS}

Table 1 summarizes the demographic data of study groups, results of MMP-3 serum levels measurement in RA and OA patients and in healthy controls and the laboratory profile of RA patients. The mean concentrations of MMP-3 were $199.1 \pm 160 \mathrm{ng} / \mathrm{mL}$ in RA patients, 113.9 $\pm 96.9 \mathrm{ng} / \mathrm{mL}$ in $\mathrm{OA}$ patients and $48.3 \pm 19.2 \mathrm{ng} / \mathrm{mL}$ in heathy controls.

The differences in serum concentrations of MMP-3 were statistically significant between RA and controls $(P<0.0001)$, between RA and OA groups $(P=0.008)$ as well as between non-RA and controls $(P=0.009)$. The distribution of MMP-3 in groups and the achieved levels of statistical significance are plotted using a quartile box plot in Fig. 1.

The difference in MMP-3 serum levels between CCPnegative and CCP-positive RA patients was not statistically significant $(P=0.189)$. Fig. 2 shows the distribution of MMP-3 serum levels in both subgroups. 


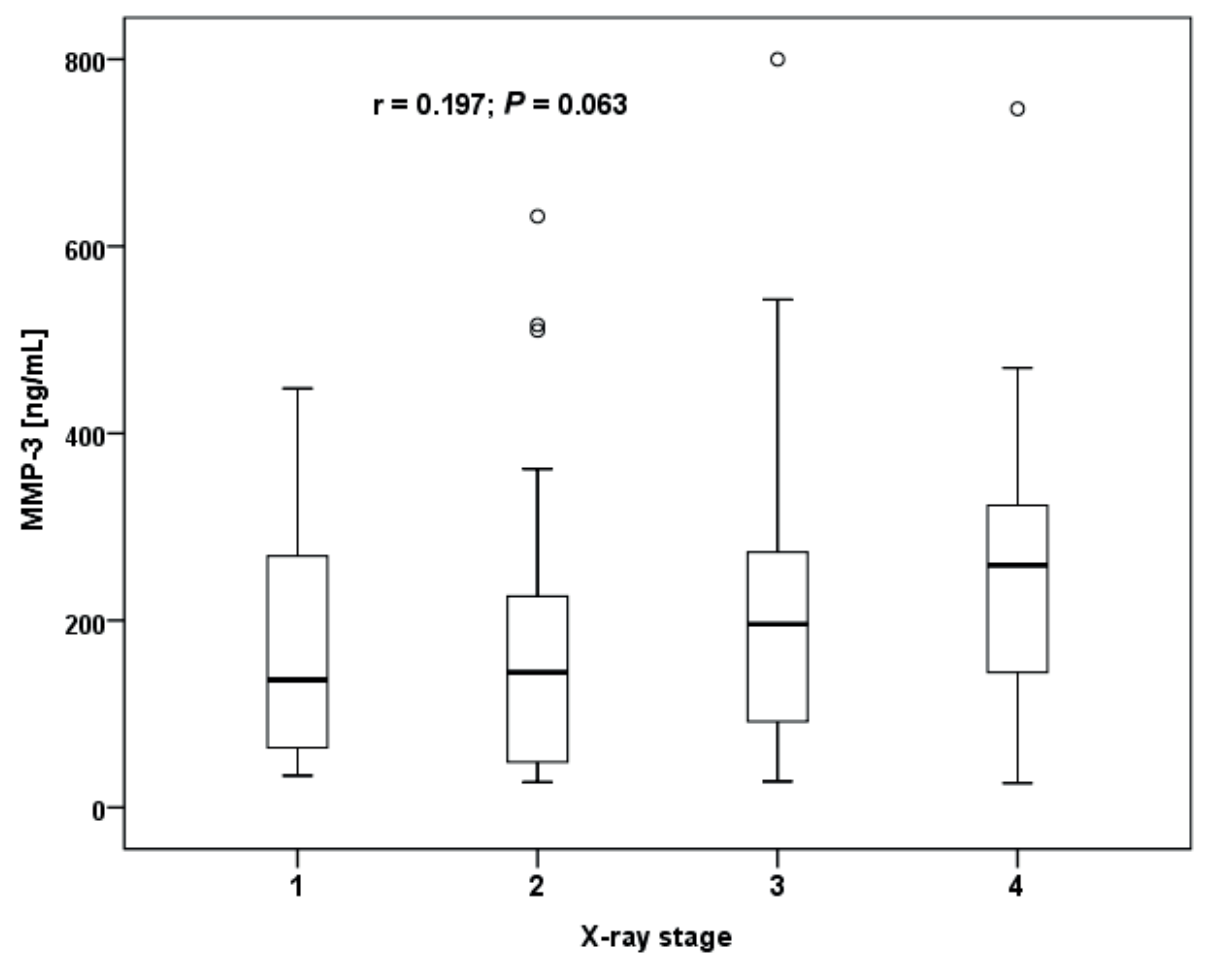

Fig. 7. Correlation between MMP-3 and radiographic stage. Box shows the distance between the quartiles, with the median as a line, and the whiskers show minimum and maximum values of MMP3. Outliers are shown as separate points.

MMP-3 concentrations were further compared with other laboratory parameters and clinical and radiographic data.

Spearman's correlation analysis showed correlations between MMP-3 and DAS28 ( $\mathrm{r}=0.301, P<0.05$; Fig. 3), CRP (r=0.304, $P<0.01$; Fig. 4), ESR ( $\mathrm{r}=0.200, P=0.059$; Fig. 5), CCP antibodies ( $\mathrm{r}=0.241, P<0.05$; Fig.6), and radiographic stage ( $\mathrm{r}=0.197, P=0.063 ;$ Fig. 7 ). No correlation was found between MMP-3 and RF.

\section{DISCUSSION}

The MMP family includes both classical enzymes secreted in a latent form and enzymes anchored in the membrane. Under physiological conditions, the activities of MMPs are regulated at the level of transcription, interaction with specific ECM components and inhibition by endogenous inhibitors. Tissue inhibitors of metalloproteinases (TIMPs) are specific inhibitors that participate in controlling the local activities of MMPs in tissues. The increasing knowledge of the structures of MMPs and of the signal transduction pathways that control MMP gene expression may provide new opportunities for therapy and development of new medicaments ${ }^{23,24}$. MMP-3 is one of the most important proteases involved in cartilage degradation; it is mainly secreted by synovial cells, fibroblasts and cartilage cells and may be activated by several cytokines such as IL- 1 and TNF- $\alpha$. MMP-3 in synovial fluid may directly degrade the cartilage and bone and mediate the development of RA. The serum levels in patients with active RA are markedly elevated in comparison with those in remission. MMP-3 expression is regulated by a promoter gene and exhibits polymorphism with the $5 \mathrm{~A} / 6 \mathrm{~A}$ alleles, but the effect of MMP-3 gene polymorphism on the development of RA is still not clear ${ }^{25}$. Burrage et al. described the role of MMPs in the process of collagen degradation. The authors mention that the expression of other MMPs such as MMP-1, MMP-2, MMP-3, MMP-9 and MMP-13 is increased in arthritis and these enzymes degrade non-collagen matrix components of the joints. They suppose that influencing MMP gene expression might provide a new approach in the therapy of joint destruction $^{26}$.

In both RA and OA, inflammatory cytokines stimulate the production of several MMPs (e.g. MMP-1, MMP-2, MMP-3, MMP-9 or MMP-13). MMP-3 is thought to play a pivotal role in joint destruction in RA (ref. ${ }^{27,28}$ ). Some studies have demonstrated significant serum expression increase in comparison to healthy controls and its correlation with concentration in synovial fluid. Therefore, serum MMP-3 could reflect a local inflammatory process in the affected joints. High levels of serum MMP-3 can be predictive of destructive processes in the joints even in early disease ${ }^{27,29}$.

The presented study demonstrated that the serum concentration of MMP- 3 is increased in RA patients, as compared with both controls and OA patients. Moreover, 
it also correlates with disease activity assessed by the DAS28 score, ESR, CRP and serum levels of anti-CCP antibodies.

This conclusion is supported by Keyszer et al. ${ }^{30}$ investigating how MMP-1, MMP-3, TIMP-1 and MMP1/ TIMP-1 complex (MT complex) reflect the clinical activity compared to cytokines, CRP, ESR and RF. They demonstrated that the correlation of MT complex with clinical data was weaker than that of MMP-3 alone, which also reflected disease activity of RA better than cytokine levels or other markers of connective tissue turnover.

The correlation between MMP-3 and DAS28 in the present study is also concordant with results reported by Ribbens et al. ${ }^{31}$. They demonstrated that serum MMP-3 might serve as a consistent synovial derived marker of RA disease activity and that early changes of MMP-3 predict disease outcome. Serum MMP-3 as a predictor of joint destruction in RA was also dealt with by Mamehara et al. who concluded that MMP-3 could predict joint destruction for RA patients treated with non-biological DMARDs by reflecting response to the drugs ${ }^{27}$. A recent study demonstrated that low levels of MMP-3 at the onset of the disease predict a patient subgroup that exhibits no radiographic progression over 3-year methotrexate monotherapy and does not require combination therapy ${ }^{32}$. Another study found that continuously elevated serum MMP-3 may predict radiographic evidence of progression over 1 year in patients treated with various DMARDs using a treat-to-target protocol ${ }^{33}$. The above findings are also supported by those by Nawata et al. demonstrating that high levels of MMP-3 predict a poor effect of infliximab and radiographic progression, especially in joint space narrowing, with high CRP levels being a negative prognostic factor for joint erosions. If the results are confirmed in other RA populations, they could establish MMP-3 as a valuable predictor of disease outcome ${ }^{34}$.

The role of MMPs, in particular MMP-3, is currently being examined in a wide range of other diseases. High levels of MMP-3 and gene polymorphism may play an important part in the pathogenesis of cardiovascular diseases. In a study by Abd El-Aziz and Mohamed, significantly higher levels of MMP-3 were displayed in patients with acute myocardial infarction (AMI) $\left(\right.$ ref..$\left.^{35}\right)$. The role of gene polymorphism for MMP-3 in ischemic heart disease was also confirmed by Tepliakov et al. ${ }^{36}$. This finding deserves special mention particularly considering RA itself as an independent risk factor for developing ischemic heart disease.

Furthermore, MMPs are increased in infections due to their role in controlling immune responses ${ }^{37}$.

The authors of the present study are aware of its limitations. It was a cross-sectional study including patients with various stages and durations of the disease. The levels of MMP-3 could have been influenced by therapy. The authors intend to follow these patients to see the development of the disease based upon the baseline MMP-3 levels. The future study should also contain the investigation of MMP-3 polymorphism in RA and RNA as well as proteomic study.

\section{CONCLUSION}

The present study demonstrated increased serum levels of MMP-3 in RA patients compared to OA patients and healthy controls. The concentration of MMP-3 correlated with DAS28, CRP, anti-CCP, ESR and radiographic stage of the disease. These findings support the notion that MMP-3 plays an important role in the pathology of RA and that elevated serum levels may help identify patients at the highest risk for developing severe disease. By reflecting the current development in the field of MMP-3 measurement in RA as seen from other studies it becomes obvious that it represents a useful marker for prediction of joint destruction ${ }^{38}$ and helps define the risk of progression of the disease.

Acknowledgement: Supported by AZV 15-28659A, IGA_ LF_2016_014 and IGA LF 2017_015.

Author contributions: SM, HP, HZ: literature search; SM, HP, KA: clinical data collection; HZ: laboratory analysis; LK: data analysis; SM, HP, KA: manuscript writing, final approval.

Conflict of interest statement: None declared.

\section{REFERENCES}

1. Pavelka K, Vencovský J. Recommendations of the Czech Society for Rheumatology for the treatment of rheumatoid arthritis. Čes Revmatol 2010;18(4):182-91.

2. Mclnnes IB, Schett $G$. The pathogenesis of rheumatoid arthritis. $N$ Engl J Med 2011;365:2205-19.

3. Mclnnes IB, Schett G. Cytokines in the pathogenesis of rheumatoid arthritis. Nature Reviews Immunology 2007;7:429-42.

4. Jones GC, Riley GP, Buttle DJ. The role of proteases in pathologies of the synovial joint. International Journal of Biochemistry and Cell Biology 2008;40(6-7):1199-218.

5. Galliera E, Banfi G, Corsi MM. Human bone disorders: pathological role and diagnostic potential of matrix metalloproteinases. International Journal of Biochemistry and Cell Biology 2010;42(10):1590-3.

6. Manicone AM, McGuire JK. Matrix metalloproteinases as modulators of inflammation. Seminars in Cell and Developmental Biology 2008;19(1):34-41.

7. Hueber AJ, Asquith DL, Mclnnes IB, Miller AM. Embracing novel cytokines in RA - complexity grows as does opportunity! Best Practice and Research 2010;24(4):479-87.

8. Connolly M, Mullan RH, McCormick J, Matthews C, Sullivan O, Kennedy A, FitzGerald O, Poole AR, Bresnihan B, Veale DJ, Fearon U. Acute-phase serum amyloid $A$ regulates tumor necrosis factor $a$ and matrix turnover and predicts disease progression in patients with inflammatory arthritis before and after biologic therapy. Arthritis and Rheumatism 2012;64(4):1035-45.

9. Kessenbrock K, Plaks V, Werb Z. Matrix metalloproteinases: regulators of the tumor microenvironment. Cell 2010;(141):52-67.

10. Kessenbrock K, Wang CY, Werb Z. Matrix metalloproteinases in stem cell regulation and cancer. Matrix Biol;2015(44-46):184-90.

11. Beidler SK, Douillet CD, Berndt DF, Keagy BA, Rich PB, Marston WA. Multiplexed analysis of matrix metalloproteinases in leg ulcer tissue of patients with chronic venous insufficiency before and after compression therapy. Wound Repair and Regeneration 2008;16:642-8.

12. Denarie D, Constant E, Thomas T, Marotte H. Could biomarkers of bone, cartilage or synovium turnover be used for relapse prediction in rheumatoid arthritis patients? Mediators Inflamm 2014;2014:537324.

13. Ma JD, Zhou JJ, Zheng DH, Chen LF, Mo YQ, Wei XN, Yang LJ, Dai L. Serum matrix metalloproteinase-3 as a noninvasive biomarker of histological synovitis for diagnosis of rheumatoid arthritis. Mediators Inflamm 2014;2014:179284. 
14. Ma JD, Ou-Yang X, Zheng DH, Mo YQ, Zou CJ, Zhu LJ. Combined detection of serum matrix metalloproteinase- 3 and C-reactive protein in disease activity measurement in female patients with rheumatoid arthritis. Chin J Clinicians (Electronic Edition) 2013;8:3301-5.

15. Aletaha D, Neogi T, Silman AJ, Funovits J, Felson DT, Bingham CO 3rd, Birnbaum NS, Burmester GR, Bykerk VP, Cohen MD, Combe B, Costenbader KH, Dougados M, Emery P, Ferraccioli G, Hazes JM, Hobbs K, Huizinga TW, Kavanaugh A, Kay J, Kvien TK, Laing T, Mease P, Ménard HA, Moreland LW, Naden RL, Pincus T, Smolen JS, Stanislawska-Biernat E, Symmons D, Tak PP, Upchurch KS, Vencovský J, Wolfe F, Hawker G. 2010 rheumatoid arthritis classification criteria: an American College of Rheumatology/European League Against Rheumatism collaborative initiative. Ann Rheum Dis 2010;69:1580-88.

16. Altman R, Alarcón G, Appelrouth D, Bloch D, Borenstein D, Brand K, Brown C, Cooke TD, Daniel W, Gray R. The American College of Rheumatology criteria for the classification and reporting of osteoarthritis of the hand. Arthritis Rheum 1990;33:1601.

17. Instruction for Immunoscan CCPlus, document E-23-0182-12, November 2015.

18. Instruction for N Latex RF Kit, Edition July 2011.

19. Bedell SE, Bush BT. Erythrocyte sedimentation rate. From folklore to facts. Am J Med 1985;78:1001.

20. Prevoo ML, van't Hof MA, Kuper HH, van Leeuwen MA, van de Putte LB, van Riel PL.Modified disease activity scores that include twentyeight-joint counts. Development and validation in a prospective longitudinal study of patients with rheumatoid arthritis. Arthritis Rheum 1995;38:44.

21. Steinbrocker $\mathrm{O}$, Traeger GH, Battermann RC. Therapeutic criteria in rheumatoid arthritis. JAMA 1949;140:659-62.

22. Boini S, Guillemin F: Radiographic scoring methods as outcome measures in rheumatoid arthritis: properties and advantages. Ann Rheum Dis 2001,60:817-27.

23. Urata $Y$, Uesato $R$, Tanaka D, Nakamura Y, Motomura S. Treating to target matrix metalloproteinase 3 normalisation together with disease activity score below 2.6 yields better effects than each alone in rheumatoid arthritis patients: T-4 Study. Ann Rheum Dis 2012;71:534-40.

24. Shiozawa K, Yamane T, Murata M, Yoshihara R, Tsumiyama $\mathrm{K}$, Imura,S, Shiozawa S. MMP-3 as a predictor for structural remission in RA patients treated with MTX monotherapy. Arthritis Research \& Therapy 2016;18:55. doi:10.1186/s13075-016-0948-7

25. Ma MJ, Liu HC, Qu XQ, Wang JL. Matrix metalloproteinase-3 gene polymorphism and its mRNA expression in rheumatoid arthritis. Genet Mol Res 2015;14(4):15652-9. doi: 10.4238/2015

26. Burrage PS, Mix KS, Brinckerhoff CE. Matrix metalloproteinases: role in arthritis. Front Biosci 2006;11:529-43.

27. Mamehara A, Sugimoto T, Sugiyama D, Morinobu S, Tsuji G, Kawano S, Morinobu A, Kumagai S. Serum matrix metalloproteinase-3 as predictor of joint destruction in rheumatoid arthritis, treated with non-biological disease modifying anti-rheumatic drugs. Kobe J Med Sci 2010;56(3):98-7.
28. Ally MMTM, Hodkinson B, Meyer PWA, Musenge E, Tikly M, Anderson R. Serum matrix metalloproteinase-3 in comparison with acute phase proteins as a marker of disease activity and radiographic damage in early rheumatoid arthritis. Mediators of Inflammation 2013;2013:6.

29. Yamanaka H, Matsuda Y, Tanaka M, Sendo W, Nakajima H, Taniguch A, Kamatani N. Serum matrix metalloproteinase 3 as a predictor of the degree of joint destruction during the six months after measurement, in patients with early rheumatoid arthritis. Arthritis Rheum 2000:43:852-8.

30. Keyszer G, Lambiri I, Nagel R, Keysser C, Keysser M, Gromnica-Ihle E, Franz J, Burmester GR, Jung K. Circulating levels of matrix metalloproteinases MMP-3 and MMP-1, tissue inhibitor of metalloproteinases 1 (TIMP-1), and MMP-1/TIMP-1 complex in rheumatic disease. Correlation with clinical activity of rheumatoid arthritis versus other surrogate markers. The Journal of Rheumatology 1999;26(2):251-8.

31. Ribbens C, Andre B, Jaspar JM, Kaye O, Kaiser MJ, De Groote D, Malaise MG. Matrix metalloproteinase-3 serum levels are correlated with disease activity and predict clinical response in rheumatoid arthritis. The Journal of Rheumatology 2000;27(4):888-3.

32. Shiozawa K, Yamane T, Murata M, Yoshihara R, Tsumiyama K, Imura S, Shiozawa S. MMP-3 as a predictor for structural remission in RA patients treated with MTX monotherapy. Arthritis Res Ther 2016;18:55.

33. Ma J-D, Wei X-N, Zheng D-H, Mo Y-Q, Chen L-F, Zhang X, Li J-H, Dai L. Continuously elevated serum matrix metalloproteinase-3 for $3 \sim 6$ months predicts one-year radiographic progression in rheumatoid arthritis: a prospective cohort study. Arthritis Res Ther 2014;17: 289. doi: 10.1186/s13075-015-0803-2

34. Nawata M, Saito K, Fukuyo S, Hirata S, Tanaka Y. Clinically relevant radiographic progression in joint destruction in $\mathrm{RA}$ patients with abnormal MMP-3 or high levels of CRP despite 1-year treatment with infliximab. Mod Rheumatol 2016 Apr 26:1-6. [Epub ahead of print] doi:10.3109/14397595.2016.1158386

35. Abd El-Aziz TA, Mohamed RH. Matrix metalloproteinase 3 gene polymorphism and its level predict morbidity after acute myocardial infarction. Am J Clin Pathol 2016;145(1):134-9.

36. Tepliakov AT, Berezikova EN, Shilov SN, Grakova EV, Torim Iulu, Efremov AV, Safronov ID, Pustovetova MG, Karpov RS. Assessment of the role of matrix metalloproteinase-3 gene polymorphism in the development of chronic heart failure. Ter Arkh 2015;87(4):8-12

37. Collazos J, Asensi V, Martin G, Montes AH, Suárez-Zarracina T, ValleGaray E. The effect of gender and genetic polymorphisms on matrix metalloprotease (MMP) and tissue inhibitor (TIMP) plasma levels in different infectious and non-infectious conditions. Clin Exp Immunol 2015;182(2):213-9.

38. Houseman M, Potter C, Marshall N, Lakey R, Cawston T, Griffiths I, Young-Min S, Isaacs JD. Baseline serum MMP-3 levels in patients with rheumatoid arthritis are still independently predictive of radiographic progression in a longitudinal observational cohort at 8 years follow up. Arthritis Res Ther 2012;14(1):R30. doi: 10.1186/ar3734 